\title{
Khitobah dalam Perspektif Gender
}

\author{
Hani Solehatunnisa ${ }^{1 *}$, Chatib Saefullah ${ }^{1}$, Aang Ridwan $^{2}$ \\ 1,2Jurusan Komunikasi dan Penyiaran Islam, Fakultas Dakwah dan Komunikasi, UIN Sunan \\ Gunung Djati, Bandung \\ *Email : hanisholehatunisa@gmail.com
}

\begin{abstract}
ABSTRAK
Tujuan penelitian ini adalah untuk mengetahui makna pesan terkaitgender pada khutbah nikah di Kecamatan Baleendah. Penelitian ini dilakukan dengan pendekatan kualitatif denganmetode analisis wacana dari A. Van Dijk (1998) yaitu dengan menentukan tematik, skematik, dan semantik yang berhubungan dengan gender dan dianggap mampu menjabarkan makna gender pada khutbah nikah di kecamatan Baleendah. Hasil penelitian ini membuktikan bahwa tidak semua khutbah nikah mengandung bias gender yang memposisikan laki-laki lebih unggul dari perempuan. Dari 15 pesan khutbah nikah yang diteliti di Kecamatan Baleendah terdapat 12 kategori tema syariah, 9 kategori tema akidah dan akhlak, dan 8 kategori tema gender yang diklasifikasikan menjadi Akidah sebagai fondasi dalam penanaman rumah tangga, Syariah sebagai pedoman interaksi sosial dan Akhlak sebagai tema sentral dalam khutbah nikah.
\end{abstract}

Kata Kunci : Gender; Khitobah; Nikah; Pesan Dakwah.

\section{ABSTRACT}

The aim of this research is to determine the meaning of gender message in marriage khotbah in Baleendah. This research was conducted with a qualitative approach with a discourse analysis method from A. Van Dijk (1998) which determining thematic, schematic, and semantic related to gender and it is considered capable of describing the meaning of gender on marriage khotbah in Baleendah. The results of this research prove that not all marriage khotbah contain gender biases that position men superior to women. From 15 marriage khotbah messages which researched in Baleendah, there were 12 categories of sharia, 9 categories of faith and moral, and 8 categories of gender which are classified into Aqeedah as a foundation in planting households, Sharia as a guide for social interaction and Morals as a central theme in marriage khotbah.

Keywords: Gender; Khotbah; Marriage; Da'wah Massage. 


\section{PENDAHULUAN}

Pada sebuah acara pernikahan, biasanya dilengkapi dengan khutbah nikah yang diselenggarakan sebelum akad nikah. Khutbah nikah pernah di contohkan oleh Nabi Muhammad SAW ketika menikahkan putri tercintanya Fatimah Az-Zahra yang diselenggarakan sebelum pelaksanaan akad nikah. Meski demikian, status khutbah nikah tidak termasuk rukun atau wajib. Khutbah nikah disampaikan oleh tokoh agama dari pihak pengantin perempuan atau biasanya disampaikan oleh orang yang dipercaya keluarga pengantin baik dari keluarga pengantin lakilaki maupun pengantin perempuan. Durasi khutbah nikah biasanya tidak lebih dari lima belas menit. Pesan dari khutbah nikah yang disampaikan menyangkut hak dan kewajiban suami istri atau berisi prinsip-prinsip, aturan-aturan dan etika hidup berkeluarga.

Pada fakta di lapangan observasi penulis sering kali mendapati bahwa dari beberapa khutbah nikah di Kecamatan Baleendah isi khutbah yang disampaikan berkaitan dengan ketaatan perempuan terhadap suami. Titik tekan dari penelitian ini yaitu bagaimana makna pesan tentang ketaatan yang harus dilakukan seorang istri terhadap suami.Penyampaian khutbah nikah ini terkadang tidak seimbang antara porsi pesan yang disampaikan kepada perempuan dengan porsi pesan yang disampaikan kepada laki-laki.

Beberapa ungkapan dalam khutbah nikah, misalnya: "Nikah nyaéta perjanjian kanggé néng anu kawitna ditungtut patuh, nurut kanu janten rama kanu janten ibu. Saparantos nikah mah éta kataatan ngalih langkung utami kanu janten carogé" (Bahwa nikah adalah sebuah perjanjian dimana awalnya wanita dituntut patuh pada ayah dan ibunya. Setelah wali atau orang tua sang istri menyerahkan kepada suaminya). Dengan demikian, kewajiban taat kepada suami menjadi kewajiban tertinggi yang harus dipenuhi istri setelah kewajiban taatnya kepada Allah dan Rasul-Nya. Hal ini istri dituntut untuk taat pada suaminya dan mengatur rumah tangganya.Tuntutan tersebut ini menjelaskan bahwa peranan istri dan suami berbeda.Ini disebabkan karena adanya perbedaan gender. Women's Studies Encyclopedia mengatakan bahwa gender adalah suatu konsep kultural yang berupaya membuat perbedaan dalam hal peran, perilaku, mentalitas, dan karakteristik emosional antara laki-laki dan perempuan yang berkembang dalam masyarakat. (Umar, 2001: 33-34).

Ungkapan lain dari seorang penyampai khutbah nikah mengenai isi pesan khutbahnya mengatakan bahwa laki-laki adalah kepala keluarga dan perempuan adalah ibu rumah tangga, disini posisi seorang istri haruslah taat pada suami. Pernyataan ini terkandung dalam sebuah hadits, Artinya: Seandainya aku boleh menyuruh seorang sujud kepada seseorang, maka aku akan perintahkan seorang wanita sujud kepada suaminya (Hr. Turmudzi:1159)". 
H. Solehatunnisa, C. Saefullah, dan A. Ridwan.

Pada penelitian ini juga, dijumpai seorang ustadz yang mengatakan bahwa dalam sebuah rumah tangga posisi suami diibaratkan sebagai majikan dan istri merupakan pembantu. Wanita memang harus dimuliakan, namun pada dasarnya wanita harus tetap taat pada suaminya. Jika seorang wanita tidak mau taat kepada suaminya maka seorang suami akan merasa tidak dihargai dan dihormati.

Dalam pernyataan di atas ditemukan masalah terkait dengan gender, yaitu marginalisasi yang menyudutkan suatu kelompok, ketidakadilan gender yang memposisikan suatu kelompok menjadi peran kedua, menempatkan suatu kelompok pada posisi lebih rendah.Masalah tersebut perlu dilakukan penelitian menyangkut pandangan bias gender dalam khutbah nikah.Penelitian ini dilakukan di Kecamatan Baleendah.

Penelitian tentang khitobah dalam prespektif gender pernah dilakukan oleh Evi Muafiah dalam Jurnal "Kyai, Pengantin Dan Netralitas Masyarakat (Studi Analisis Gender terhadap Ceramah Agama pada Acara Resepsi Pernikahan di Ponorogo)". Penelitian ini berisi analisis ceramah yang disampaikan Da'i pernikahan mengenai nilai dan prinsip ajaran Islam dalam membentuk sebuah keluarga sakinah mawaddah wa rahmah yang mengungkapkan bias gender atau memarginalisasikan kaum perempuan. Penelitian selanjutnya oleh Abdilah Mistari dalam Jurnalnya yang berjudul "Pernikahan Islam Berkesetaraan Gender", Penelitiannya ini mengenai analisis Gender yang menjelaskan bahwa hukum Islam justru lebih menekankan pada "pembedaan gender" dalam menetapkan posisi ideal laki-laki dan perempuan.Penelitian lain juga dilakukan oleh Muhammad Nanda Rahmana dalam jurnalnya yang berjudul: "Materi Khutbah Nikah Dan Pengarubnya Terhadap Pemahaman Hak Dan Kewajiban Suami Isteri (Studi Kasus Di Masjid Raya Kecamatan Baiturrahman Banda Aceh)". Dalam penelitiannya ini, Nanda menjelaskan bahwa khutbah nikah dapat dijadikan sebagai salah satu faktor untuk meningkatkan pemahaman tentang hak dan kewajiban suami istri.

Pada uraian diatas, maka yang membedakan penelitian ini dengan penelitian-penelitian sebelumnya adalah penulis lebih mengkerucutkan kepada motif da'i pernikahan, makna pesan dakwah yang disampaikan dalam khutbah nikah dan pandangan mempelai terhadap khutbah nikah. Penelitian ini mengkaji mengenai makna pesan khitobah terkait gender di Kecamatan Baleendah. Penelitian ini dimaksudkan untuk mengetahui bagaimana keadaan pesan khitobah terkait gender pada khutbah nikah di Kecamatan Baleendah.

Dari latar belakang masalah tersebut dapat dirumuskan menjadi: Bagaimana keadaan pesan khutbah nikah dalam perspektif gender di Kecamatan Baleendah?.Pesan dakwah tidak lagi terbatas pada teks Alquran dan hadis, melainkan sebuah pemahaman maupun penafsiran sebagai buah dari interaksi antara manusia yang hidup dengan pikiran serta pengalaman dengan sumber ajaran Islam.Bahkan pesan dakwah disusun dan dirumuskan sesuai dengan 
tujuan dakwah.(Fuadi, 2017: 326).

Metode yang digunakan pada penelitian ini adalah analisis wacana dari A. Van Dijk (1998) yaitu dengan menentukan tematik (Struktur Makro), skematik (Superstruktur), dan semantik (Struktur Mikro) yang berhubungan dengan gender yang dianggap mampu menggambarkan dan menjabarkan makna pesan dibalik khitobah terkait gender pada pesan khutbah nikah di kecamatan Baleendah.

Menurut Alex Shobur (2011:72-73) Struktur Makro dari pesan khutbah nikah di Kecamatan Baleendah adalah tema tentang gender. Superstruktur adalah kerangka suatu teks tentang bagaimana struktur kamilat bisa terbentuk seperti apa yang di perlihatkan.Struktur Mikro adalah makna wacana yang diamati dengan menganalisis kata, kalimat, proposisi, anak kalimat, parafrase yang di pakai (Nursyamsi, 2018 :99-100).

Dalam pesan khutbah nikah terkait gender di Kecamatan Baleendah dikategorikan menjadi beberapa tema, menurut Samsul Munir Amin (2009: 89) mencakup kultur Islam yang murni yang bersumber dari kedua sumber tersebut dengan memperhatikan situasi dan kondisi masyarakat. Secara umum materi pesan dakwah yang bersumber dari ajaran Islam dibagi menjadi tiga macam.Keimanan (Aqidah) kepercayaan kepada Allah SWT, Tentang tauhid. Keislaman (Syariat), hukum, peraturan sistem keislaman yang disyari'atkan oleh Allah SWT untuk umat manusia. Budi Pekerti (Akhlak) atau moral merupakan pendidikan jiwa agar jiwa seseorang dapat bersih dari sifat-sifat yang tercela dihiasi dengan sifat terpuji. Menyeru atau mengajak merupakan inti dalam proses (Ismail, 2018: 25-26).

Penelitian ini dilakukan dengan pendekatan kualitatif dan menggunakan data primer yakni isi pesan yang terkandung dalam khutbah nikah.pengumpulan data ini melalui observasi, wawancara tidak terstruktur baik internal maupun eksternal yang didukung oleh dokumentasi yang relevan dalam penelitian ini dan rekaman suaraa isi khutbah nikah yang kemudian dituangkan ke dalam bentuk tulisan.

\section{LANDASAN TEORITIS}

Amir, (2009: 145) mengungkapkan Dakwah merupakan suatu proses komunikasi yang khas dan dapat dibedakan dari bentuk komunikasi yang lainnya dari beberapa segi yaitu: siapa pelakunya (komunikator), apa pesan pesannya (message), bagaimanakah caranya (approach), apa yang menjadi tujuannya (destination) dan siapa yang menerimanya (komunikan)(Nurjanah, 2019 :35).

Sukayat (2009:92) mendefinisikan bahwa khitobah menurut bahasa berasal dari akar kata, khataba, yakthubu, kbutbatanatau khitobatan yang artinya: berkhutbah, berpidato, meminang, melamar,bercakap-cakap, mengirim surat. 
H. Solehatunnisa, C. Saefullah, dan A. Ridwan.

Sedangkan Aliyudin(1995:57) mendefinisikan khitobah merupakan ceramahatau pidato yang disampaikan oleh mubaligh kepada jamaah (mad'u) untuk menyampaikan ajaran-ajaran Islam melalui media lisan baik berupa ibadah mahdhoh maupun yang tidak terikat dengan ibadah mahdhoh.

Chudlori, (2012: 55) menyatakan, Ketika proses khitbah dimulai, di Sunnah kan untukmelakukan khutbah terlebih dahulu. Kegiatan khutbah tersebut untukmenasihati antara kedua belah pihak.Setelah itu peminangan (ji'tukum fikarimatikum) saya mendatangi kalian untuk melamar wanita mulia kalian.Apabila diwakilkan maka wakilnya yang berkata (jïtukum anbu khotibankharimatakum) saya mendatangi kalian sebagai ganti dari orang yangmewakilkan kepadaku untuk melamar wanita mulia kalian (Ismail, 2018: 26).

"Khutbah nikah disebut juga sebagai khutbatul hajah, yaitu khutbah pembuka yang biasanya digunakan oleh Rasulullah SAW untuk mengawali setiap majelisnya. Rasulullah juga mengajarkan khutbah ini kepada para sahabatnya"(Yazid, 2006: 65).

Pada penelitian ini mengkaji mengenai khitobah terkait gender pada khutbah nikah. "Kata "jender" berasal dari Bahasa Inggris, Gender, berarti "Jenis Kelamin". Webster's New World Dictionary, mendefinisikan Gender sebagai "Perbedaan yang tampak antara laki-laki dan perempuan dilihat dari segi nilai dan tingkah laku" (Umar, 2001:34).

"Dalam Women's Studies Encyclopedia mengatakan bahwa gender adalah suatu konsep kultural yang berupaya membentuk perbedaan dalam hal peran, perilaku, mentalitas, dan karakteristik emosional antara laki-laki dan perempuan yang berkembang dalam masyarakat" (Umar, 2001: 33-34).

Dari berbagai definisi di atas dapat disimpulkan bahwa jender adalah suatu konsep yang digunakan untuk mengidentifikasi perbedaan laki-laki dan perempuan dilihat dari segi sosial-budaya.Jender dalam arti ini mengidentifikasikan laki-laki dan perempuan dari sudut non-biologis. Ada beberapa Teori Gender yang dikemukakan oleh Nasarudin Umar, yaitu:

Pertama, Teori Psikoanalisa/Identifikasi. Teori ini pertama kali diperkenalkan oleh Sigmud Freud (1856-1939)(Umar, 2001).Teori ini menjelaskan bahwa perilaku dan kepribadian laki-laki dan perempuan sejak awal ditentukan oleh perkembangan seksualitas.Freud menjelaskan kepribadian seseorang tersusun atas tiga struktur, yaitu $I d$, ego, superego.Tingkah laku sesorang menurut Freud ditentukan oleh interaksi ketiga struktur itu.Pertama, Id, sebagai sifat-sifat bawaan fisik-biologis seseorang sejak lahir termasuk nafsu seksual dan insting yang selalu cenderung selalu agresif. Kedua, Ego, prilaku dalam lingkup rasional dan berupa melunakan keinginan agresif dan id. Ketiga, superego, berfungsi sebagai aspek moral dalam kepribadian, berfungsi mewujudkan kesempurnaan hidup, lebih dari sekedar mencari kesenangan dan kepuasan.Superego juga selalu mengingatkan ego agar senantiasa melakukan 
fungsinya mengontrol Id (Umar, 2001: 45).

Kedua, Teori Fungsionalis Struktural. Teori ini berangkat dari pandangan bahwa suatu masyarakat terdiri dari berbagai bagian yang saling mempengaruhi.Teori ini menggali unsur-unsur mendasar yang berpengaruh di dalam suatu masyarakat, mengidentifikasi fungsi setiap unsur, dan menjelaskan bagaimana fungsi unsur-unsur tersebut di dalam masyarakat (Umar, 2001).Dalam bukunya Nassarudin Umar mengatakan Menurut Lipsada beberapa unsur pokok dalam teori fungsionalis struktural yang sekaligus menjadi kekuatan teori ini, yaitu: Pertama, Kekuasaan dan Status, Dorothy Dinnerstein dan Nancy Chodorow mengemukakan bahwa Perempuan dinilai berpenampilan dan berprilaku lemah lembut, sementara laki-laki berpenampilan dan berprilaku tegar dan jantan, dan karenanya memiliki kekuasaan dan status lebih besar (Umar, 2001). Kedua, Komunikasi Non-Verbal menurut Nancy Henley Dan J. Freeman sebagai kemampuan kurang (less powerful) bagi perempuan dan kemampuan lebih (more powerful) bagi laki-laki. Laki-laki lebih dimungkinkan untuk menegur sapa kepada kepada perempuan daripada perempuan(Umar, 2001). Ketiga, Perempuan di dalam Berbagai Organisasi yaitu Kedudukan perempuan di dalam berbagai organisasi diperhatikan secara khusus oleh Robert Moss Kanter's. Menurutnya, ketimpangan peran Jender di dalam berbagai organisasi disebabkan karena perempuan mempunyai berbagai keterbatasan(Umar, 2001). Keempat, "Rape-Prone" dan "Rape-Free" yaitu Perempuan adalah mahkluk yang rawan untuk diperkosa (Rape-Prone) sementara laki-laki tidak rawan untuk diperkosa (Rape-Free). Berbagai kejahatan seksual dapat dilakukan oleh laki-laki terhadap perempuan, tetapi tidak sebaliknya. Dari sudut pandang ini disadari atau tidak, laki-laki mendapatkan keuntungan dalam pola relasi jender, walaupun keadaanya sangat tergantung pada setiap kondisi masyarakat(Umar, 2001). Kelima, Pembagian kerja yaitu dalam masyarakat tradisional dikenal pembagian kerja secara seksual, laki-laki sebagai pemburu (bunter) dan perempuan sebagai pengasuh (nurturer) (Umar, 2001: 51).

Ketiga, Teori Konflik. Teori ini berangkat dari asumsi bahwa dalam susunan di dalam suatu masyarakat terdapat beberapa kelas yang saling memperebutkan pengaruh dan kekuasaan. Marx yang kemudian dilengkapi oleh Friedrich Engels dalam bukunya Nassarudin Umar mengemukakan suatu gagasan menarik bahwa perbedaan dan ketimpangan gender antara laki-laki dan perempuan, tidak disebabkan oleh perbedaan biologis, tetapi merupakan bagian dari penindasan dari kelas yang berkuasa dalam relasi produksi yang diterapkan dalam konsep keluarga. Hubungan suami-istri tidak ubahnya dengan hubungan proletar dan borjuis, hamba dan tuan, pemeras dan yang diperas (Umar, 2001: 61).

Keempat, Teori Feminis. Pandangan feminis terhadap perbedaan peran jender laki-laki dan perempuan secara umum dapat dikategorikan kepada tiga 
H. Solehatunnisa, C. Saefullah, dan A. Ridwan.

kelompok yaitu: Feminisme Liberal: Tokoh aliran ini antara lain Margaret Fuller (1810-1850), Harriet Martineau (1802-1906), Angelina Grimke (1792-1873) dan Susan Anthony (1820-1906) (Umar, 2001). Dalam pemikiran ini adalah semua manusia laki-laki dan perempuan diciptakan seimbang dan serasi dan mestinya tidak terjadi penindasan antara satu dengan lainnya. Feminisme Marxis-Sosialis: Aliran ini mulai berkembang di Jerman dan di Rusia dengan menampilkan beberapa tokohnhya, seperti: Clara Zetkin (1857-1933) dan Rosa Luxemburg (1871-1919)(Umar, 2001). Aliran ini berupaya menghilangkan struktur kelas dalam masyarakat berdasarkan jenis kelamin dengan melontarkan isu bahwa ketimpangan peran antara kedua jenis kelamin itu sesungguhnya lebih disebabkan oleh faktor budaya alam. Feminisme Radikal: Aliran ini muncul dipermulaan abad ke-19 dengan mengangkat isu besar, menggugat semua lembaga yang dianggap merugikan perempuan seperti lembaga patriarki yang dinilai merugikan perempuan, karena term ini jelas-jelas menguntungkan laki-laki (Umar, 2001: 64).

Kelima, Teori Sosio-Biologis. Teori ini dikembangkan oleh Pierre van den Berghe, Lionel Tiger dan Robin Fox (Umar, 2001) dan intinya bahwa Intensitas keunggulaan laki-laki tidak saja ditentukan oleh faktor biologis tetapi elaborasi kebudayaan atas biogram manusia. Teori ini disebut "bio-sosial" karena melibatkan faktor biologis dan sosial dalam menjelaskan relasi jender (Umar, 2001: 68).

Dari uraian diatas dapat disimpulkan bahwa makna pesan khitobah terkait gender pada khutbah nikah di Kecamatan Baleendah akan lebih efektif jika dikaji dengan menggunakan teori-teori gender.

\section{HASIL DAN PEMBAHASAN}

Pada Bulan Oktober 1982 merupakan cikal bakal berdirinya Kecamatan Baleendah yang definitif, hal ini ditandai dengan berdirinya Kantor Perwakilan Kecamatan Baleendah yang merupakan pecahan dari Kecamatan Ciparay (Kel. Baleendah, Kel. Manggahang dan Kel. Jelekong) dan Kecamatan Pamengpeuk (Kel. Andir, Desa Rancamanyar, Desa Malakasari dan Desa Bojong Malaka). Berdasarkan Peraturan Pemerintah Nomor 44 Tahun 1992 Kantor Perwakilan Kecamatan Baleendah ditingkatkan statusnya menjadi Kantor Kecamatan Baleendah dan diresmikan oleh Gubernur Jawa Barat YOGI S MEMET pada tanggal 28 Oktober 1992.

Penduduk di Kecamatan Baleendah berjumlah 245.889 jiwa, terdiri dari: Laki-laki 125.639 jiwa dan Perempuan 120.250 jiwa. Kepadatan Penduduk di Kecamatan Baleendah berjumlah 7.011 jiwa / km. Lingkungan/Dusun 15 Lingk/Dusun, Rukun Warga (RW) sebanyak 146 RW, Rukun Tetangga (RT) sebanyak 963 RT, Desa/Kelurahan sebanyak 3/5 Desa/Kel dan Desa 
Swasembada sebanyak 3 Desa.

Angka NTCR (Nikah Talak Cerai, Rujuk) pada data Nikah sebanyak 1.783 kejadian.Dari tahun-ketahun Data Pernikahan di Kecaamatan Baleendah mengalami kenaikan.Berdasarkan hasil penelitian terdapat delapan tema khutbah nikah dalam perspektif genderdi Kecamatan Baleendah, diklasifikasikan menjadi:

\section{Pesan Akidah sebagai Fondasi dalam Penanaman Rumah Tangga}

Pada kehidupan berumah tangga diperlukan penanaman akidah yaang mendalam untuk membentuk rumah tangga yang sakinah, mawadah, dan rahmah. Kunci hidup rukun dalam rumah tangga berasal dari akidah yang baik. Akidah memiliki pengaruh yang sangat besar terhadap kehidupan rumah tangga.

Ada beberapa pesan khutbah nikah mengenai gender yang berkaitan dengan akidah, dalam kutipan khutbah nikah ustadz Dadih. Kutipannya sebagai berikut: "Komo deui ka hidep kanu kasép, hidep kedah nahan gogoda" (Ust. Dadih, 4/5/19). Dijelaskan bahwa seorang suami harus menjaga sikap terhadap wanita lain yang mana seorang laki-laki mempunyai peran yang lebih tinggi dibanding perempuan dalam hal mendekati lawan jenis. Dalam pesan khutbah nikah tersebut menjelaskan bahwa laki-laki yang sudah menikah harus setia terhadap istrinya.

Kalimat yang disampaikan tersebut sangat berkaitan dengan Teori Marx yang mengatakan bahwa perbedaan dan ketimbangan gender antara laki-laki dan perempuan tidak ditemtukan oleh perbedaan biologis tapi merupakan bagian dari penindasan kelas yang berkuasa dalam relasi produksi yang diterapkan pada sitem keluarga (Marzuki, 1999: 7).

Meski pada dasarnya seorang laki-laki mempunyai peran besar terhadap keluarga namun seorang laki-laki harus mampu bersikap adil dalam membangun rumah tangga. Seorang laki-laki setelah menikah harus setia dan bersikap baik kepada istrinya, juga mampu menjaga perasaan istrinya. Rasulullah SAW pernah berkata Aisyah pada hadits yang panjang mengenai Ummu Zar: "Aku dan dirimu bagaikan Abu Zar dan Ummu Zar. Maksudnya: aku dan kamu seperti mereka berdua dalam hal cinta dan kesetiaan. Kesetiaan merupakan cermin cinta, ketulusan, dan pengorbanan kaum wanita yang harus dihargai dengan prilaku yang sama dalam rangka mencari ridha-Nya. Hal ini juga dijelaskan dalam Quran Surat An-Nur; 30 yang artinya: "Katakanlah kepada laki-laki yang beriman, agar mereka menjaga pandangannya, dan memelihara kemaluannya yang demikian itu lebih suci bagi mereka. Sungguh, Allah Maha Mengetahui apa yang mereka perbuat" (Depag RI, 2008).

Menurut Nasaruddin Umar dalam bukunya Gender dalam Perspektif Islam menjelaskan bahwa Perbedaan laki-laki dan perempuan sering dilihat dari segi biologis, hal ini berhubungan dengan Teori Fungsionalis Struktural dengan 
H. Solehatunnisa, C. Saefullah, dan A. Ridwan.

kekuatan Komunikasi Non-Verbal yang menjelaskan laki-laki lebih memungkinkan untuk melakukan interaksi awal terhadap perempuan daripada sebaliknya. Hal ini dijelaskan dalam Quran Surat An-Nisa; 32 yang artinya:

"Dan janganlah kamu iri hati terhadap apa yang dikaruniakan Allah kepada sebahagian kamu lebih banyak dari sebahagian yang lain. (Karena) bagi orang laki-laki ada bahagian dari pada apa yang mereka usahakan, dan bagi para wanita (pun) ada bahagian dari apa yang mereka usahakan" (Depag RI, 2008).

Munculnya isu kesetaraan antara laki-laki dan perempuan dilatarbelakangi adanya ketidakpuasan perlakuan terhadap kaum perempuan. Tidak jarang dijumpai kasus-kasus yang mendeskriditkan kaum perempuan, bahkan menghilangkan makna keberadaannya. Kepada laki-laki dan perempuan tidaklah dibeda-bedakan berdasarkan jenis kelamin untuk memperoleh kedudukan yang mulia di sisi-Nya, keduanya mempunyai kesempatan untuk mendapatkan pahala maupun keduanya dapat tergelincir kedalam dosa (Rahminawati: 2001: 276).

The International Women's Tribune Centre menyatakan sejak perempuan dan laki-laki mempunyai peran gender yang berbeda dan melakukan jenis pekerjaan yang berbeda, mereka mempunyai tingkat akses yang berbeda pula terhadap pelayanan dan sumber-sumber daya dan mengalami relasi yang timpang. Kebutuhan perempuan dan laki-laki bisa juga berbeda. Kebutuhan praktis gender adalah kebutuhan perempuan dalam peran sosial mereka dan masyarakat yang diterima secara sosial. Mereka tidak menentang meskipun kebutuhan itu muncul dari pembagian kerja berdasarkan gender dan posisi subordinasi perempuan dalammasyarakat. Kebutuhan ini beragam sesuai dengan konteks tertentu yang dihubungkan dengan pembagian kerja berdasarkan gender, kekuasaan, dan kontrol termasuk juga adanya isu-isu seperti hak hukum, kekerasan dalam rumah tangga, persamaan upah, dan kontrol perempuan atas tubuhnya (Fabriar, 2016: 11).

Dengan demikian, seorang perempuan berhak mendapatkan kebebasan dan keleluasaan dalam berhubungan, ada kalanya seorang istri melakukan kesalahan dan tugas seorang suami mendidik juga mengajarkan kebaikan kepada istrinya. Dalam Islam dijelaskan bahwa perempua tidak berada pada posisi terendah dibandingkan laki-laki baik dari segi penciptaanya, tugas dan fungsi, maupun hak dan kewajiban. Di dalam Al-Quran dan As-Sunnah, Perempuan mempunyai derajat yang setara dan seimbang dengan laki-laki, bahkan Allah sudah sangat memuliakan kaum perempuan.

\section{Pesan Syariah sebagai Pedoman Interaksi Sosial}

Pesan syariah adalah sumber hukum yang melahirkan peradaban Islam. Syariah menjadi penguat dalam peradaban di kalangan kaum Muslim. Dalam berumah tangga diperlukan adanya hukum-hukum yang mendasari, sehingga pesan syariah 
berperan penting menjadi pedoman dalam berumah tangga, diantaranya: (1) Suami harus memimpindan memberi nafkah lahir dan batin terhadap istri. (2) Istri harus menggembirakan hati suami ketika dipandang, apabila diperintah ia mentaati, apabila ditinggal ia mampu menjaga kehormatan diri dan harta.

Dalam terwujudnya ketentraman dan ketenangan hati dalam rumah tangga, suami istri harus menjalankan tanggung jawabnya masing-masing. Ada beberapa pesan khutbah nikah mengenai gender yang berkaitan kewajiban suami istri. Kutipan khutbah nikah tersebut, diantaranya: 'kawajiban nu janten carogé nyandak nu janten bojo kana jalan mardotillah jalan anu dipikacinta ku Allah SWT" (Ust. Tarmana, 28/4/19). Pada kutipan tersebut seorang penceramah menjelaskan bahwa kewajiban seorang suami adalah membawa istrinya kepada jalan yang diridhai Allah. Selain itu pesan lain menyangkut kewajiban istri, "anu janten bojo taat kana kawajiban anu janten carogé kitu mangrupikeun hiji perkara matak tiasa mukakeun kana lawang panto surgana Allah SWT" (Ust. Tarmana, 28/4/19), Bahwa dikatakan seorang istri harus taat dan patuh kepada suami sebab itu adalah suatu jalan membukakan pintu surga.

Pada kalimat pesan yang disampaikan tersebut sangat berkaitan dengan Teori Fungsionalis Struktural menurut Lips dalam bukunya Nassarudin Umar, teori ini menjelaskan bagaimana fungsi suatu unsur di dalam masyarakat.Unsur pokok yang menjadi kekuatan. Teori Fungsionalis Struktural yang berkaitan dengan kutipan pesan tersebut yaitu Kekuasaan dan Status.Dorothy Dinnerstein dan Nancy Chodorow dalam bukunya Nasaruddin Umar mengemukakan perbedaan laki-laki memiliki kekuasaan lebih besar dan status lebih tinggi daripada perempuan karena Perempuan dinilai berpenampilan dan berprilaku lemah lembut, sementara laki-laki berpenampilan dan berprilaku tegar dan jantan, karenanya memiliki kekuasaan dan status lebih besar (Umar, 2001: 51).

Pada pesan ini bahwa kewajiban seorang suami adalah membawa istrinya kepada Jalan yang diridhai Allah karena memiliki peran lebih tinggi di atas perempuan. Begitu sebaliknya, seorang istri harus mampu taat kepada suami dengan tujuan Allah akan membukakan pintu surga bagi pasangan tersebut. Hal ini dijelaskan dalam Quran Surat At-Tahrim ayat 6 yang artinya:

"Hai orang-orang yang beriman, periharalah dirimu dan keluargamu dari api neraka yang bahan bakarnya adalah manusia dan batu: penjaganya malaikat-malaikat yang kasar, keras, dan tidak mendurhakai Allah terhadap apa yang diperintah-Nya kepada mereka dan selalu mengerjakan apa yang diperintahkan” (Depag RI, 2008).

Dalam Perspektif Islam menjelaskan bahwa Perempuan dan laki-laki kedudukannya sama dihadapan Allah. Ayat yang menegaskan bahwa: "Para lakilaki (suami) adalah pemimpin para perempuan (istri)" (QS. An-Nisa:34). Namun kepemimpinan seorang laki-laki ini tidak boleh menjadi sewenang-wenang, 
H. Solehatunnisa, C. Saefullah, dan A. Ridwan.

karena dari satu sisi Al-Quran memerintahkan laki-laki dan perempuan untuk tolong menolong dan dari sisi lain Al-Quran memerintahkan pula agar suami dan istri hendaknya bermusyawarah permasalahan mereka bersama serta keduanya harus berkomunikasi menjalin diskusi agar tidak ada kesalahpahaman antar keduanya.

Dalam terciptanya rumah tangga yang aman, nyaman, damai, tentram yakni perlu adanya sikap saling menghargai dari pasangan.Nikah adalah ibadah terlama sehingga dalam rumah tangga diperlukan adanya adab-adab yang mendukung kekuatan bangunan rumah tangga.Ada beberapa pesan khutbah nikah mengenai gender yang berkaitan dengan adab suami istri, yaang dijelaskan Ustadz Otih, "Allah seneng kanu seungit-seungitan, tempat obo tempat naon supaya sarareungit sunnah meunang pahala ibadah" (Ust. Otih, 24/5/19), dikatakan bahwa seorang istri harus mampu menjaga kebersihan rumahnya untuk membuat suami nyaman, Allah mencintai hamba-Nya yang menjaga diri dari kebersihan sebab itu suatu amalan yang sunnah.

Pada kalimat pesan yang disampaikan penceramah tersebut sangat berkaitan dengan Teori Fungsionalis Struktural. (Ratna Megawangi, 1999: 56) Teori ini berangkat dari asumsi bahwa suatu masyarakat terdiri ataas beberapa baagian yang saling memengaruhi. Teori ini mencari unsur-unsur mendasar yang berpengaruh di dalam suatu masyarakat, mengidentifikasi fungsi dan setiap unsur dan menerangka bagaimana fungsi unsur-unsur tersebut dalam masyarakat. Pengikut teori ini menunjuk masyarakat pra industri yang terintegrasi di dalam suatu sistem sosial. Laki-laki berperan sebagai pemburu (hunter) dan perempuan sebagai peramu (gatherer). Sebagai pemburu, laki-laaki lebih banyak berada di luar rumah dan bertanggung jawab untuk membawa makanan kepada keluarga. Peran perempuuan lebih terbatas di sekitar rumah dalam urusan reproduksi, seperti mengandung, memelihara, dan menyusui anak. Pembagian kerja yang seperti ini berhasil menciptakan keberlangsungan masyarakat yang stabil. Dalam masyarakat ini stratifikasi peran gender sangat ditentukan oleh seks (jenis kelamin) (Marzuki, 1990: 4-5).

Seorang istri tidak boleh meremehkan kebersihannya, sebab kebersihan sebagian dari iman. Dia harus selalu mengikuti sunnah, seperti membersihkan dirinya, mandi, memakai minyak wangi dan merawat dirinya agar ia selalu berpenampilan bersih dan harum di hadapan suaminya. Rasulullah SAW bersabda: "sebaik-baik istri adalah yang menyenangkan jika engkau melihatnya, taat jika engkau menyuruhnya serta menjaga dirinya dan hartamu disaat engkau pergi."

Rahminawati dalam jurnalnya mengkategorikan gender menjadi beberapa hal: perempuan mengerjakan rumah tangga, sedangkan laki-laki dianggap tidak pantas. Tugas laki-laki mengelola kebun, tugas peremupuan hanya membantu. Menjadi pemimpin lebih pantas oleh laki-laki. program kesehatan keluarga leebih 
pantas oleh perempuan (Rahminawati, 2001: 274)

Umar menjelaskan dalam bukunya bahwa suami dan istri keduanya mempunyai hubungan yang saling menyempurnakan dalam istilah Al-Quran "ba dhukum mim ba'dhi" "sebagaian kamu (laki-laki) adalah sebagian dari yang lain (perempuan)." Bahkan laki-laki dan perempuan dikatakan hubungan timbal balik terkandung dalam QS. Al-Baqarah:187, “istri-istri kamu adalah pakaian untuk kamu (para suami) dan kamu adalah pakaian untuk mereka."

Dengan demikian pekerjaan rumah tangga di masyarakat hampir semua dilakukan oleh kaum perempuan sedangkan pekerjaan memimpin dan mencari nafkah keluarga adalah tugas seorang laki-laki. Namun demikian, sudah sepatutnya suami dan istri saling membantu tugas satu sama lain yang mana ketika istri membutuhkan pertolongan suami dan suami membutuhkan pertolongan istri keduanya sama-sama mau dan mampu menolong.

\section{Pesan Akhlak Sebagai Tema Sentral dalam Khutbah Nikah}

Akhlak adalah suatu perilaku/sikap yang mencerminkan kepribadian setiap individu. Berdasarkan khutbah nikah di kecamatan Baleendah, pesan akhlak yang disampaikan diantaranya: (1) Peran suami selain harus memimpin dan memberi nafkah lahir dan batin terhadap istri, suamipun harus memberikan kenyamanan terhadap istri mereka. . (2) Suami harus menjaga diri dari berbagai godaaan, misalnya: media social. (3) Suami dan istri harus saling menerima kekurangan satu sama lain. (4) Suami tidak boleh 'otoriter' yang tidak menerima segalana sehat dan masukan dari istri. (5) Kebahagiaan tidak harus dengan uang. Namun kebahagiaan bisa dengan saling memberi pengertian satu sama lainnya. (6) Suami dan istri harus menjaga pandangan dari bukan mahromnya.

Pada akad nikah yang telah berlangsung dan sah menuhi syarat rukunnya, maka akan berlaku hak dan kewajiban suami istri. Dalam hidup berumah tanggaa suami dan istri wajib mengetahui peranan masing-masing. Ada beberapa pesan khutbah nikah mengenai gender yang berkaitan dengan kewajibaan suami istri, diantaranya beberapa kutipan: "Maparinanan nafkah lahir sareng batina oge supaya kumaha carana salami nu janten bojo nyaman aya di bawah pimpinanna salaku nu janten carogé", "Istri yang baik adalah wanita yang menggembirakan hatimu ketika dipandang, apabila kamu perintah ia mentaatimu, apabila kamu tiada ia mampu menjaga kehormatan dirinya dan hartamu" (Ust. Tarmana, 28/4/19).

Kutipan tersebut menjelaskan bahwa selain suami wajib memberikan nafkah lahir dan batin terhadap istrinya, ia juga harus memberikan kenyamanan kepada istri selama berada di bawah pimpinan suami. Dan istri yang baik adalah ia yang ketika diperintah mentaati suaminya dan mampu menjaga kehormatan dirinya dan hartanya. Karena ridha Allah tergantung ridha suami. 
H. Solehatunnisa, C. Saefullah, dan A. Ridwan.

Kalimat pesan yang disampaikan penceramah tersebut sangat berkaitan dengan Teori Fungsionalis Struktural menurut Lips dalam bukunya Nassarudin Umar, teori ini menjelaskan bagaimana fungsi suatu unsur di dalam masyarakat. Unsur pokok yang menjadi kekuatan Teori Fungsionalis Struktural yang berkaitan dengan kutipan pesan tersebut yaitu pembagian kerja.Menurutnya pembagian lapangan kerja menjadi pembeda antara laki-laki dan perempuan. Dalam masyarakat tradisional dikenal pembagian kerja secara seksual, posisi lakilaki sebagai pemburu dan perempuan sebagai pengasuh, hal yang sama pun masih dijumpai pada masyarakat modern. Misalnya dalam dunia bisnis, perempuan diposisikan menjadi sekretaris dan laki-laki yang memimpin (Umar, 2001: 51).

Analisis Gender (Nurlian dan Dasulay, 2008) tidak hanya melihat perbedaan peran dan kegiatan antara laki-laki dan perempuan, tetapi juga melihat relasi mereka. Dari relasi ini akan nampak status perempuan dan laki-laki. pembagian kerja gender adalah pola pembagian kerja antara pasangan suami istri yang disepakati bersama, serta didasari oleh sikap yang saling memahami dan saling mengerti (Probosiwi, 2015: 49).

Peran suami sebagai pemimpin rumah tangga memiliki kewajiban memberi nafkah kepada istri. Disamping suami memberi nafkah lahir, ia juga wajib memberi nafkah batin. Hal ini dijelaskan dalam Quran Surat Al-Baqarah: 223 yang artinya:

"Istri-istrimu adalah ladang bagimu, maka datangilah ladangmu itu kapan saja dengan cara yang kamu sukai. Dan utamakan (yang bai) untuk dirimu. Bertakwalah kepada Allah dan ketahuilah bahwa kamu kelak akan menemui-Nya. Dan sampaikanlah kabar gembira kepada orang yang beriman"(Depag RI, 2008).

Pada rumah tangga penting adanya akhlak baik suami dan istri.Keduanya sama-sama memiliki kewajiban yang harus dilaksanakan. Akhlak yang baik inilah yang akan menjadi kekuatan dalam membangun rumah tangga. Ada beberapa pesan khutbah nikah mengenai gender yang berkaitan dengan Akhlak suami istri, diantaranya beberapa kutipan: "Jadi urang kudu narima sagala kekurangan, nampi sagala kakurangan baik ti carogé atanapi sagala kakurangan anu aya di bojo"(Ust. Otih, 24/5/19), seorang penceramah dalam salah satu khutbah nikah juga mengatakan "jagalah pandangan mata kalian berdua" (Ust.Ahmad, 6/7/19) dalam hal ini baik suami atau istri keduannya harus saling memahami kekurangan masingmasing dan menjaga diri diantara keduanya karena terciptanya rumah tangga yang baik itu dengan saling menjaga, menghargai, menghormati dan memahami.

Kalimat pesan yang disampaikan tersebut sangat berkaitan dengan Teori Psikoanalisa/Identifikasi oleh Sigmud Freud dalam buku Nasaruddin Umar. Menurutnya manusia itu memiliki tiga struktur yang menjelaskan kepribadian seseorang yaitu $i d$ atau disebut dengan sifat bawaan (hawa nafsu) dan ego disebut 
dengan keinginan diri yang bersifat rasional.Namun kedua struktur kepribadian itu dikendalikan dan dikontrol oleh Superego atau disebut dengan tingkah laku (Marzuki, 1990:12).

Hadits lain Rasulullah SAW memberi nasihat kepada para sahabatnya: "Pergaulilah istri dengan baik. Sesungguhnya mereka diciptakan dari tulang rusuk.Tulang rusuk yang paling bengkok adalah yang paling atas. Jika kamu hendak meluruskannya, maka akan patah. Jika kamu biarkan makan akan tetap bengkok. Maka pergauli istrimu dengan baik."(HR.Bukhari).

Hadits tersebut menjelaskan bahwa keburukan apapun yag ada pada diri istri harus dimengerti suami dan keburukan yang ada pada suami harus dimengerti istri, sebab istri harus mengetahui bahwa ridha Allah tergantung ridha Suami.

Menjaga pandangan dalam rumah tangga juga termasuk kunci Kesetiaan dan merupakan cermin cinta, ketulusan, dan pengorbanan kaum wanita yang harus dihargai dengan prilaku yang sama dalam rangka mencari ridha-Nya. Hal ini juga dijelaskan dalam Quran Surat An-Nur; 30-31 yang artinya:

"Katakanlah kepada laki-laki yang beriman, agar mereka menjaga pandangannya, dan memelihara kemaluannya yang demikian itu lebih suci bagi mereka. Sungguh, Allah Maha Mengetahui apa yang mereka perbuat" (Depag RI, 2008).

"Dan katakan kepada para perempuan yang beriman agar mereka menjaga pandangannya dan memelihara kemaluannya, dan janganlah menampakan perhiasannya (Auratnya)" (Depag RI, 2008).

Kutipan lain yang berkaitan dengan khutbah nikah perspektif gender, diantaranya: "Ulah sampé ka dicarék bojo hoyong nyarios ka aa "cicing manéh mah nyaho naon" (Ust. Awa, 30/6/19). Dijelaskan dalam pesan khutbah tersebut bahwa seorang suami tidak berhak melarang istrinya dalam berbicara. Meskipun seorang suami memiliki derajat lebih tinggi diatas perempuan, tapi ia harus tetap memuliakan.

Kalimat yang disampaikan tersebut mengatakan bahwa semua manusia laki-laki dan perempuan diciptakan seimbang dan serasi.Seharusnya tidak terjadi penindasan antara satu dengan lainnya. Karena setiap jenisnya sudah Allah tentukan porsi dari masing-masing. Seorang istri juga tidak boleh dihina, dicaci atau dikatakan kepadanya perkataan yang buruk.Termasuk dilarang berkata kotor dan kasar. Istri haruslah dimuliakan agar ia juga memuliakan suami. Hal ini juga dijelaskan dalam Quran Surat Ali-Imran ayat 159 yang artinya:

"Maka berkat rahmat Alla engkau (Muhammad) berlaku lemah lembut terhadap mereka.Sekiranya engkau bersikap keras dan berhati kasar, tentulah mereka menjauhkan diri dari sekitarmu.Karena itu maafkanlah mereka dan mohonkanlah ampunan untuk mereka, dan bermusyawarahlah 
H. Solehatunnisa, C. Saefullah, dan A. Ridwan.

dengan mereka dalam urusan itu.Kemudian, apabila engkau telah membulatkan tekad, maka bertakwalah kepada Allah.Sungguh, Allah mencintai orang yang bertawakal'(Depag RI, 2008).

Diriwayatkan ada seorang lelaki datang kepada Umar bin Khathab r.a dengan maksud mengadukan kejelekan istrinya. Lelaki itu berdiri di depan rumah Umar menunggu beliau keluar. Kebetulan ia mendengar istri Umar menjelekjelekan Umar dengan ucapannya. Sedangkan Umar bin Khathab diam saja tidak menjawab. Lelaki itu kembali seraya berkata, "Kalau keadaan Amirul Mukminn seperti ini apalagi saya."'Tak lama kemudian Umar keluar melihat lelaki itu mundur kembali, lalu dipanggil dan ditegur, “apa keperluanmu?”Jawab lelaki itu, "Wahai Amirul Mukminin, saya datang untuk mengadukan kejelekan istriku yang sangat menyakitkan saya.Lalu saya tahu ternyata istrimu juga demikian, apalagi keadaanku." Sahut Umar, "Wahai saudaraku! Aku butuh ucapan jelek istriku, karena hak-hak istriku yang mesti aku cukupi.Istriku memasak maakanan, membuat roti untukku, mencuci pakaianku dan menyusi anakku.Hatiku tentram karena terhindar dari perkara haram lantaran pelayanan istriku.Maka dialah sebagai jaminannya", Lelaki itu berkata "Wahai Amirul Mukminin, Istriku juga demikian", "Oleh karena itu, sabarlah wahai saudaraku ini hanya sebentar!" jawab Umar.

Rasulullah pernah bersabda: "Mukmin yang paling sempurna imannya adalah yang paling baik akhlaknya, dan sebaik-baik kalian adalah yang paling baik akhlaknya terhadap istri-istrinya." (Hr. Tirmidzi).

Kewajibaan dan akhlak suami istri adalah hal yang wajib dilakukan setiap pasangan, namun adab suami istri juga menjadi peran penting dalam rumah tangga.Terciptanya rumah tangga yang sejahtera dihasilkan dari adab suami istri yang baik. Ada beberapa pesan khutbah nikah mengenai gender yang berkaitan dengan Adab Suami Istri, diantaranya beberapa kutipan:"titip 3 P nya kasép nya. P Naon? P nu kahiji Pang Ngimahankeun cing Pageuh, Pang Makéankeun cing Weuteuh, Pang Numpakankeun dugi ka reuneuh"(Ust. Unang, 7/7/19). Pesan ini disampaikan kepada pengantin laki-laki bahwa menjadi suami perlu memberi istri rumah, memberi istri pakaian dan membuat istri hamil.

Pada kalimat pesan yang disampaikan tersebut sangat berkaitan dengan Teori Fungsionalis Struktural menurut Lips dalam bukunya Nassarudin Umar, teori ini menjelaskan bagaimana fungsi suatu unsur di dalam masyarakat.Unsur pokok yang menjadi kekuatan Teori Fungsionalis Struktural yang berkaitan dengan kutipan pesan tersebut yaitu "Rape-Prone" dan "Rape-Free". Teori ini menjelaskan bahwa Perempuan adalah mahkluk yang rawan untuk diperkosa (Rape-Prone) sementara laki-laki tidak rawan untuk diperkosa (Rape-Free). Laki-laki mungkin melakukan pemerkosaan terhadap perempuan namun tidak sebaliknya.Dari sudut pandang ini, laki-laki mendapatkan keuntungan dalam pola relasi jender, walaupun keadaanya sangat tergantung pada setiap kondisi 
masyarakat (Umar, 2001: 51).

Menurut Michel Foucault dan Heidi Harman dalam bukunya Nasaruddin Umar menjelaskan Meskipun teori ini banyak memperoleh kritikan dan kecaman, teori ini masih tetap bertahan terutama karena didukung oleh masyarakat industri yang cenderung tetap mempertahankan prinsip-prinsip ekonomi industri yang menekankan aspek produktivitas. Jika faktor produksi diutamakan, maka nilai manusia akan tampil tidak lebih dari sekedar alat produksi. Nilai-nilai fundamental kemanusiaan cenderung diabaikan. Karena itu, tidak heran dalam masyarakat kapitalis, "inddustri seks" dapat diterima secara wajar. Yang juga memperkuat pemberlakuan teori ini adalah karena masyarakat modern-kapitalis (Marzuki, 1990: 6).

Pada pesan ini menjelaskan bahwa seorang suami berkewajiban memberi nafkah lahir dan batin kepada istri. Hal ini dijelaskan dalam Quran Surat AlBaqarah ayat 223 yang artinya:

"Istri-istrimu adalah ladang bagimu, maka datangilah ladangmu itu kapan saja dengan cara yang kamu sukai. Dan utamakan (yang bai) untuk dirimu. Bertakwalah kepada Allah dan ketahuilah bahwa kamu kelak akan menemui-Nya. Dan sampaikanlah kabar gembira kepada orang yang beriman"(Depag RI, 2008).

Pada dasarnya Allah memerintahkan suami untuk menggauli istrinya dengan cara yang disukai. Hadits lain menyebutkan bahwa seorang suami diperintahkan untuk menggauli istrinya dengan baik., yakni: " pergaulilah istri dengan baik. Sesungguhnya mereka diciptakan dari tulang rusuk.Tulang rusuk yang paling bengkok adalah yang paling atas. Jika kamu hendak meluruskannya, maka akan patah. Jika kamu biarkan, maka akan tetap bengkok. Maka pergauli istri dengan baik." (HR. Bukhari).

Umar menjelaskan Gender dalam Perspektif Islam bahwa laki-laki dan perempuan derajatnya sama di hadapan Allah, namun suami adalah pemimpin dalam keluarga, kepemimpinan suami lebih atas satu derajat dibanding seorang istri dan seorang suami bertanggung jawab atas kebutuhan hidup keluarganya. Laki-laki dan perempuan adalah insan yang saling membutuhkan Hal ini diungkapkan Al-Quran dengan Istilah "ba dhukum mim ba'dhi" "sebagaian kamu (laki-laki) adalah sebagian dari yang lain (perempuan).'Hubungan suami dan istri hakikatnya adalah saling menyempurnakan.

\section{PENUTUP}

Posisi khutbah dalam Islam yakni untuk menyampaikan berita gembira dan peringatan guna memberikan kesadaran, mengingatkan, menimbulkan ketenangan dan kenyamanan, berpandangan dan berprilaku sesuai pesan yang disampaikan penceramah dalam khutbahnya.

Pelaksanaan khutbah Nikah biasa dilaksanakan pada acara resepsi sebelum 
H. Solehatunnisa, C. Saefullah, dan A. Ridwan.

akad nikah, tujuannya adalah memberi nasehat berupa arahan kepada pengantin yang akan memulai rumah tangga. Nasehat tersebut menunjukan bahwa khutbah nikah ini mengandung pesan yang banyak membahas persoalan suami istri dalam urusan ibadah kepada Allah.

Berdasarkan penelitian yang penulis lakukan terhadap Khutbah Nikah di Kecamatan Baleendah guna menemukan pesan dakwah utama pada khutbah nikah dan pesan khutbah terkait gender, maka dari 15 pesan khutbah nikah terdapat 12 kategoritemapesansyariah, 9 kategoritemapesanakidahdanakhlak, 8 kategori tema pesan terkait gender. Dari 8 temapesanterkait gender diantaranya diklasifikasikan menjadi: Akidah sebagai fondasi dalam penanaman rumah tangga, Syariah sebagai pedoman interaksi sosial dan Akhlak sebagai tema sentral dalam khutbah nikah.

Untuk menggambarkan lebih jelas pesan dakwah yang disampaikan dalam khutbah nikah di Kecamatan Baleendah, penceramah memberi gambaran dan penguat berupa hadits dan Quran yang menjelaskan kewajiban suami istri.Sehingga pesan khutbah yang disampaikan semakin memperjelas penyampaian pesan.

Pada hasil penelitian ini beberapa pesan khutbah nikah memang mengandung pesan terkait gender yang memposisikan peran laki-laki lebih unggul dibanding perempuan. Namun tidak semua penceramah khutbah nikah memarginalkan kaum perempuan.Karenanuansa bias gender tidak begitu terlihat dalam pesan khutbah nikah di Kecamatan Baleendah sebab kerangka keseluruhan ceramahnya sangat umum.

Dari isi pesan khutbah nikah di Kecamatan Baleendah tersebut dapat disimpulkan bahwa pada dasarnya seorang istri memang dituntut patuh dan taat kepada suami, namun seorang suami juga harus mampu memuliakan istri.Kaum perempuan jangan merasa dirinya rendah di hadapan laki-laki karena Allah sudah sangat memuliakan kaum perempuan.

Berdasarkan hasil pengamatan dan penelitian terhadap khutbah nikah di Kecamatan Baleendah. Penulis ingin memberikan saran, diantaranya: Pertama, Untuk KUA, Sebaiknya kementrian agama memberikan taining atau pengarahan kepada penghulu atau penyampai khutbah agar dalam penyampaian khutbah nikah bisa lebih disempurnakan pembahasannya. Kedua, Untuk penceramah khutbah nikah seharusnya diberikan pelatihan khusus dalam menyampaikan isi khutbah nikah karena Kebanyakan penceramah khutbah nikah kurang menyampaikan hal-hal berkenaan dengan hak-hak dan kemulian wanita dalam khutbah nikahnya, penyampaian khutbah tentang kemulian wanita tidak sebanyak penceramah menyebutkan tugas wanita. Ketiga, Untuk peneliti selanjutnya diharapkan dapat meneliti lebih dalam pesan dakwah terkait gender pada khutbah nikah. Keempat, Untuk masyarakat yang menghadiri proses resepsi dan mendengar khutbah nikah diharapkan tidak hanya menjadikan khutbah 
sebagai sebuah tausiah semata tetapi juga dapat medengar dan memahami makna yang terdapat pada khutbah nikah yang disampaikan. Karena khutbah nikah memiliki banyak sekali makna pesan dakwah di dalamnya, khusus kepada pengantin dan umum kepada masyarakat.

\section{DAFTAR PUSTAKA}

Aliyudin, E. 1995. Dasar-dasar Ilmu Dakwah. Bandung: Tim Widya.

Depag RI. 2008. AL-Quran dan Terjemah. Bandung: CV Diponegoro.

Fabriar. S. R. 2016. Representasi Perempuan dalam Jurnal An-Nida 8(1).

Fuadi, M. H. 2017. Pesan Dakwah Hasan Al-Banna dalam Jurnal Ilmu Dakwah: Academic Journal for Homiletic Studies 11(2) 325-340.

Ismail, N, 2018. Pesan Dakwah tentang Nikah di Media Sosial Instagram.Bandung dalam Tabligh Jurnal Komunikasi dan Penyiaran Islam3 (1), $22-45$.

Jawas. A. Q, Y. 2006. Bingkisan Istimewa Menuju Keluarga Sakinah. Bogor: Keluarga At-Taqwa.

Marzuki. 1990. Kajian Awal Tentang Teori-teori Gender dalam Jurnal Fakultas Tarbiyah LAIN Sunan Kalijaga Yogyakarta: 1-15.

Muafiah, E. 2010. Kyai, Pengantin ddan Netralitas Masyarakat: Studi Analisis Gender terhadap Ceramah Agama pada Acara Resepsi Pernikahan di Ponorogo, Vol 4 No.1 2010).

Nurjanah, T. 2019. Dakwah Kelompok dalam Komunitas Pejuang Mahar dalam Jurnal Anida(Aktualisasi Nuansa Ilmu Dakwah) 19 (1), 34-49.

Nursyamsi, Y. F. 2018. Analisis Wacana Pesan Dakwah pada Film Cinta dalam Ukhwah dalam Tabligh Jurnal Komunikasi dan Penyiaran Islam.

Probosiwi. 2015. Perempuan dan Perannya dalam Pembangunan Kesejahteraan Sosial (Woman and its Role on Social Welfare Development). Jurnal Natapraja (ilmu administrasi negara) 3(1), 41-56.

Rahminawati, N. 2001. Isu Kesetaraan Laki-laki dan Perempuan (Bias Gender) dalam Jurnal Fakultas Tarbiyah UNISBA 3 (XVII) 271-283.

Sukayat, T. 2009. Quantum Dakwah. Bandung: Simbiosa Rekatama Media.

Umar, N. 2001. Argumen Kesetaraan Jender Perspektif AL-Quran. Jakarta: PT. Sapdodadi. 